UDC 666.94:543.57

L.Ya. Parashchuk ${ }^{a}$, V.V. Kochubey ${ }^{b}$, L.I. Odosiy ${ }^{a}$, S.V. Korolko ${ }^{a}$

\title{
RESEARCH INTO THE PROTECTIVE CHARACTERISTICS OF SPECIAL-PURPOSE CEMENT-BASED CONCRETES
}

\author{
${ }^{a}$ Hetman Petro Sahaidachnyi National Army Academy, Lviv, Ukraine \\ ${ }^{\mathrm{b}}$ Lviv Polytechnic National University, Lviv, Ukraine
}

\begin{abstract}
The effect of the cement type, from which engineering protective constructions are produced, on the value of the linear absorption coefficient of radiation flow has been investigated. The chemical and mineralogical composition of cement for the protective concrete was selected so that hydrated new-formations with the highest possible content of chemically bound water can be formed when hardened. The differential thermal analysis was conducted using a derivatograph Q-1500 D of Paulic-Paulic-Erdey system. Based on the obtained data, the quantitative composition of hydration products of cements under study was determined. A change in radiation intensity (in becquerel) was experimentally measured after passing through the concrete samples based on the Portland cement PC II/A-S 400 and the expansive Portland limestone cement PLC-5. Using the law of the weakening of a narrow monoenergetic beam of $\gamma$-quanta after passing through a substance, a linear absorption coefficient was calculated for the concrete samples of different composition. By means of special mechanical and physicochemical methods, the relationships between the processes of structure formation and the protective characteristics of the samples have been established. It was shown that hydrated compounds formed in the course of hydration of a cement constituent allow increasing the linear absorption coefficient together with raising the level of protection.
\end{abstract}

Keywords: cement, hydrated new-formations, hydration products, radioactive emission, absorption coefficient, thermal analysis.

DOI: $10.32434 / 0321-4095-2019-124-3-139-144$

\section{Introduction}

Nowadays, an increasing threat from reconnaissance and sabotage forces, illegal armed groups and terrorist groups necessitates solving the problem of protection of important objects and personnel from the means of defeating the enemy. For this purpose, fortifications and engineering buildings are used, which are designed to improve the effectiveness of the military equipment and provide sustainable protection of troops and population [1-4].

Current local armed conflicts require a new approach to the creation of modern defense-related materials or the improvement of existing ones. Among the materials used for defense purposes, various shelters and constructions are widely used that are built on the basis of both ordinary and special-purpose cements $[5,6]$.

An analysis of the results of armed conflicts that took place over the past half century in the world and in particular in the area of counterterrorist operation in Ukraine shows that the enemy neglects any existing arrangements and uses the weapons that are best suited to achieve the objective assigned. For example, there are large-caliber 122- and 152-mm shells or depleted uranium shells, the former being highly destructive. The main danger from the shells with depleted uranium consists in the consequences of their employment [7-9]. When inhaled or swallowed, fine dust formed during an explosion under the influence of high temperature leads to the radiation exposure and heavy metal poisoning of a human body [10].

Thus, one can conclude that the protection of personnel and equipment is insufficient for the accomplishment of tasks in modern conditions. Therefore, the purpose of this work was to study the properties of building materials for the production

(c) L.Ya. Parashchuk, V.V. Kochubey, L.I. Odosiy, S.V. Korolko, 2019 
of special-purpose constructions having defined characteristics.

\section{Material and methods}

Complex differential-thermal, X-ray phase and thermogravimetric analyses were used to study the structure formation processes.

The X-ray analysis of the samples was carried out according to the method of powder using a DRON-2.0 diffractometer with $\mathrm{CuK}_{\alpha}$ radiation. The thermal analysis was aimed at identifying the temperatures at which changes in physical conditions of the samples or in their chemical compositions can be observed. The thermograms were recorded by a derivatograph Q-1500 D of Paulic-Paulic-Erdey system. The composition of samples was analyzed dynamically and in air at the rate of heating of $5^{0} / \mathrm{min}$. The weight of the substance was $500 \mathrm{mg}$, the sensitivity by DTA scale and by TG scale was equal to $250 \mu \mathrm{V}$ and $100 \mathrm{mg}$, respectively. In order to carry out the X-ray phase and thermal analyses, the samples after dehydration were crushed in an agate mortar until they fully penetrate through the sieve No. 008.

Physical and mechanical tests were performed in compliance with the European standards $[9,10]$. We examined the compressive and bending strength of fine concrete and used the test beam $(4 \times 4 \times 16 \mathrm{~cm})$ and test cube $(7.07 \times 7.07 \times 7.07 \mathrm{~cm})$. The samples were tested using a hydraulic press $\mathrm{P}-50$.

A radioactive substance $\left({ }^{137} \mathrm{Cs}\right)$ placed in a lead container with a small opening was used as a source of radioactive emission (Fig. 1, (1)). The radioactive emission was directed to concrete samples (2) of the same thickness. The radiation intensity after penetrating through the barrier was measured using Geiger-Mueller gas-discharge tube (3). The amount of registered particles of radioactive emission was counted by the electric pulse counter (5).

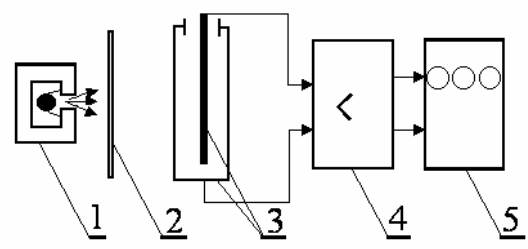

Fig. 1. Scheme of laboratory facility for determination of linear absorption coefficient of radioactive emission: 1 - radiation source; 2 - absorptive concrete; 3 - Geiger-Mueller counter tube; 4 - power supply of Geiger-Mueller counter; 5 - electric pulse counter

\section{Results and discussion}

High-density and hydrated concrete is a constructional material that is utilized to buld radiation-proof shelters for protection against neutron and $\gamma$-radiation. In this case, cement acts as a generator of hydrated compounds that absorbs neutrons whereas its aggregates take $\gamma$-radiation. Barite, iron ore, scrap metal are used as aggregates. Fineness of aggregates for protective concretes is determined by massiveness of a construction that is concreted and deemed to be maximally possible. Aggregate size is selected so that to ensure the maximum possible saturation of concrete by heavyweight aggregates. The heavier is the concrete obtained, the less can be the building's thickness.

Chemical and mineralogical composition of the cement for protective concrete should be such that, when hardened, hydrated new-formations can be formed with the most possible content of chemically bound water. Experience in using aluminous, super sulfated, expansive cements, and also a magnesian binder (that is called Sorel cement) is known [7].

Since there are no deposits of the abovementioned aggregates in Ukraine, and they are expensive, the study was performed using Portland cement PC II/A-S M400 and expansive Portland limestone cement PLC-5 (according to Ukrainian specifications TU U 26.5-02071010-141-2010).

The features of binders' hydration process were studied using physical and chemical methods of analysis, in particular, the X-ray phase analysis. Fig. 1 shows the following reflexes of hydration products: portlandite $(\mathrm{d} / \mathrm{n}=0.263 ; 0.493 \mathrm{~nm})$, ettringite $(\mathrm{d} / \mathrm{n}=$ $=0.561 ; 0.973 \mathrm{~nm})$ and calcite $(\mathrm{d} / \mathrm{n}=0.302 \mathrm{~nm})$; their intensity gradually increases after 90 days of hardening. However, the diffraction peakes of nonhydrating cement $(\mathrm{d} / \mathrm{n}=0.218 ; 0 / 260 ; 0 / 277 \mathrm{~nm})$ tend to naturally decline during the hydration.

The use of PLC-5 is characterized by a notable increase of reflexes of calcium hydroxide, ettringite and a type $\mathrm{C}_{4} \mathrm{AH}_{13}$ hydroaluminates $(\mathrm{d} / \mathrm{n}=1.073 \mathrm{~nm})$ that appear in the subsequent term of hardening (28 days). The presence of excessive amount of $\mathrm{Ca}(\mathrm{OH})_{2}$ contributes to the formation of elongated prismatic crystals of primary ettringite and calcite that yield a strength carcass, provide an intensive set of physicalmechanical properties, and also increase the amount of chemically bound water.

The quantitative composition of hydration products of cements under investigation was confirmed by the comprehensive thermogravimetric and differential thermal analyses (Fig. 3). The data of thermal analysis confirmed the results of the Xray phase analysis. The mass loss of the samples manifests itself at four stages and is accompanied by endothermic effects in the DTA curves. 


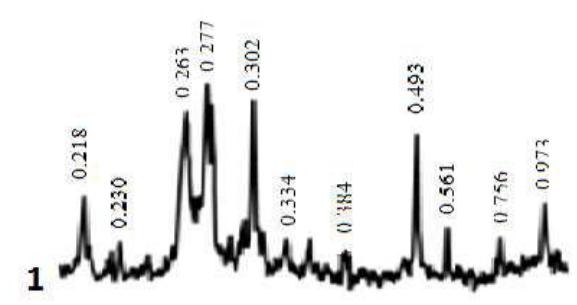

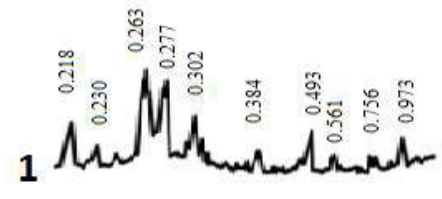
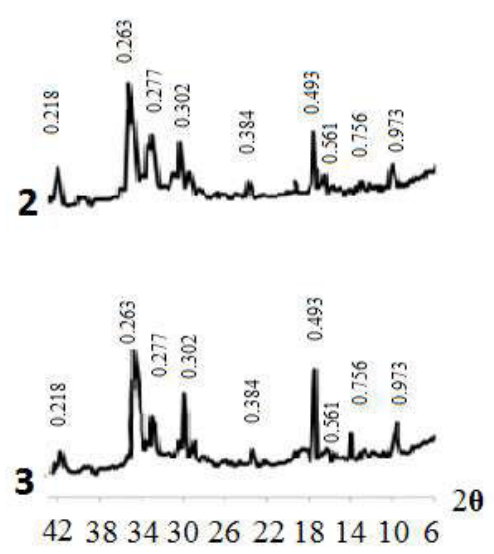
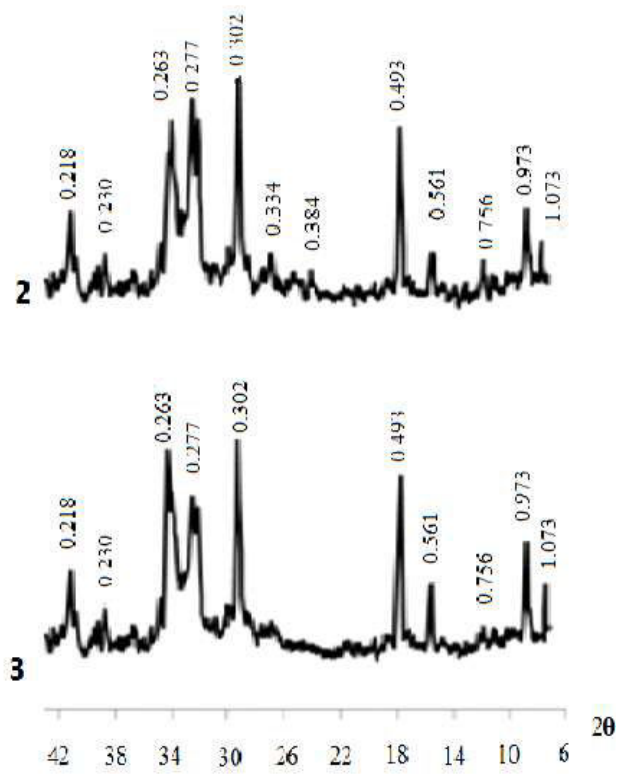

b

Fig. 2. X-ray patterns of cement stone based on the Portland cement PC II/A-S 400 (a) and expansive Portland limestone cement PLC-5 (b) hardened for: (1) 7 days; (2) 28 days; (3) 90 days

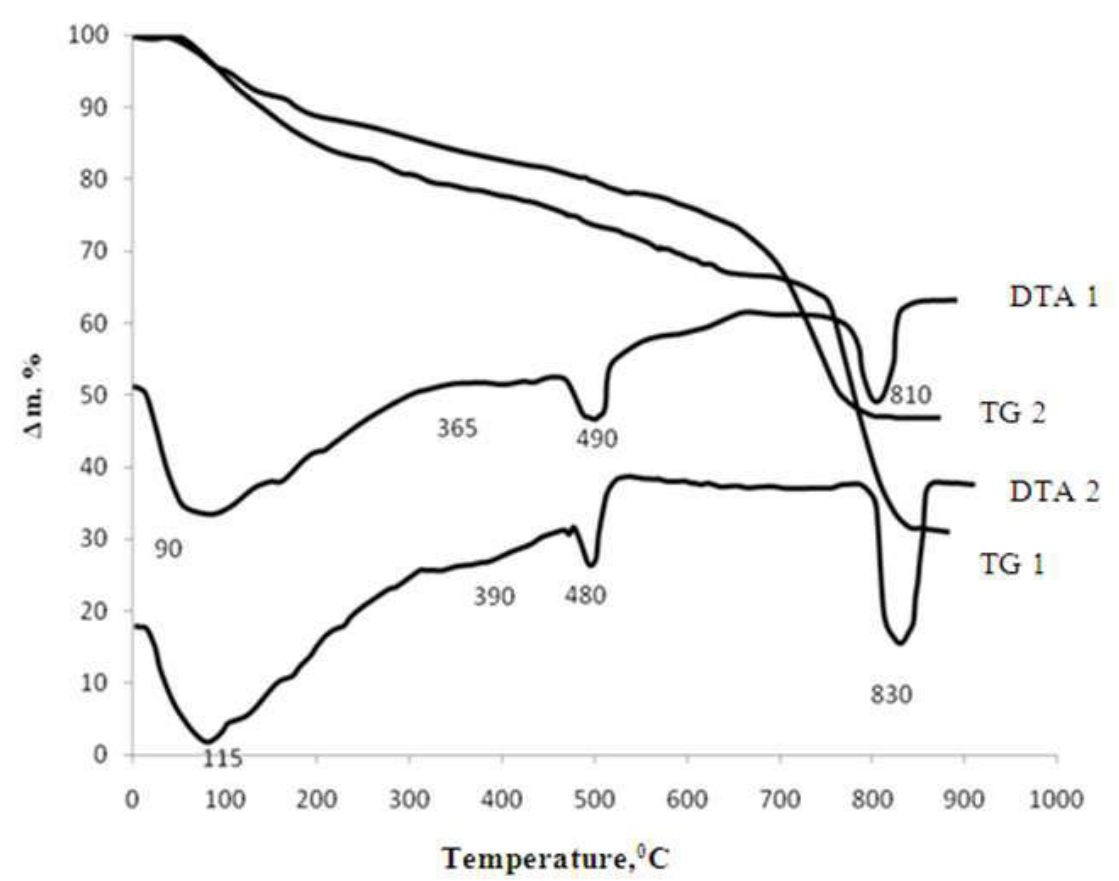

Fig. 3. Thermograms of cement stone hardened for 7 days under normal conditions: (1) expansive Portland limestone cement PLC-5; (2) Portland cement PC II/A-S 400 
A decrease in mass within a temperature range of $20-140^{\circ} \mathrm{C}$ (Table) can be attributed to the discharge of residual physical moisture and in part to the chemically bound water. Low basic hydrosilicates of the group $\mathrm{CSH}(\mathrm{II})$ together with ettringite, which are present in both samples, lose hydrated water in this region. The mass loss of the samples at temperatures of $130^{\circ} \mathrm{C}$ to $330^{\circ} \mathrm{C}$ corresponds to the continuation of a step-by-step dehydration of hydrosilicates and ettringite as well as to the start of decomposition of hydroaluminates. The samples of expansive Portland limestone cement PLC-5 exhibit a larger loss of mass in this interval, which can be explained by larger $\mathrm{CAH}_{10}$ content in them. The mass reduction at temperatures of 310$450^{\circ} \mathrm{C}$ is associated with the final breakdown of hydrosilicates and decomposition of hydroaluminates of the group $\mathrm{CAH}_{10}$ present in the layer close to $\mathrm{CaO}$ granules. The sample 1 reveals a higher loss of mass within the given temperature range due to a higher content of high basic hydroaluminates in it. The mass reduction of the samples in the temperature range of $440-550^{\circ} \mathrm{C}$ corresponds to portlandite decomposition. A further mass loss at the temperatures of $550-1000^{\circ} \mathrm{C}$ can be attributed to the final breakdown of hydroaluminates and calcite.

Thus, based on the thermal analysis of the samples 1 and 2, the conclusion can be drawn that the samples intermediate zone exhibits a higher content of hydrated phases. This is confirmed by more dramatic mass loss of the sample when heated in all temperature ranges, followed by deeper endothermic effects accompanying decomposition of the samples of hydration products.

To determine the protection efficiency, it is necessary to carry out experimental measurement of changes in radiation intensity (in becquerel) after passing through the concrete samples based on the Portland cement PC II/A-S 400 and expansive Portland limestone cement PLC-5. The laboratory installation illustrated in Fig. 1 was used for this purpose.

Using the law of the weakening of a narrow monoenergetic beam of $\gamma$-quanta after passing through a substance, a linear absorption coefficient was calculated for the concrete samples of different composition and average results were obtained. The samples based on the Portland cement PC II/A-S revealed the value of absorption coefficient of 0.124 while the expansive Portland limestone cement PLC-5 based samples showed the value of 0.152 . The value of attenuation coefficient of the samples which contain a higher amount of hydrated new-formations was $22 \%$ higher than that for the samples based on ordinary Portland cement. From these results, one can conclude that using the cement that provides formation of higher amount of hydrated compounds will yield a higher level of protection. The defined value of attenuation coefficient of quantum radiation correlates with the results obtained by physical and chemical studies.

\section{Conclusions}

Our findings showed that the chemical composition of binder in concrete has a considerable effect on the protective properties of a shielding material. Due to the formation of a higher amount of hydrated compounds in hydration, changing a type of cement from the ordinary Portland cement PC II/A-S 400 to the expansive Portland limestone cement PLC-5 enables increasing the linear

Results of DTA of cements hardened for seven days

\begin{tabular}{|c|c|c|c|c|}
\hline No & Type of cement & Temperature range, ${ }^{0} \mathrm{C}$ & Mass loss $(\Delta \mathrm{m}), \%$ & Endothermic effect, $\mathrm{T}_{\max },{ }^{0} \mathrm{C}$ \\
\hline \multirow{6}{*}{1} & \multirow{6}{*}{$\begin{array}{l}\text { Expansive Portland } \\
\text { limestone cement } \\
\text { PLC-5 }\end{array}$} & $20-130$ & 2.25 & 115 \\
\hline & & $130-310$ & 2.5 & undetectable \\
\hline & & $310-450$ & 1.125 & undetectable \\
\hline & & $450-550$ & 1 & 490 \\
\hline & & $550-1000$ & 5.0 & 810 \\
\hline & & $20-1000$ & 11.875 (total loss) & $\begin{array}{llll}- & \\
\end{array}$ \\
\hline \multirow{6}{*}{2} & \multirow{6}{*}{$\begin{array}{l}\text { Portland cement } \\
\text { PC II/A-S } 400\end{array}$} & $20-140$ & 2 & 90 \\
\hline & & $140-330$ & 2 & undetectable \\
\hline & & $330-440$ & 0.75 & undetectable \\
\hline & & $440-550$ & 0.75 & 480 \\
\hline & & $550-1000$ & 2.9 & 830 \\
\hline & & $20-1000$ & 7.4 (total loss) & - \\
\hline
\end{tabular}

Note: $T_{\max }$ is the temperature of the maximum endothermic effect. 
absorption coefficient of radiation flow by almost $25 \%$ and hence reducing the thickness of the protective layer. Besides, the thickness of the protective seam of construction can be reduced.

\section{REFERENCES}

1. Cheung Y.K., Chau K.W. Tall buildings - from engineering to sustainability. - World Scientific, 2005. - 1168 p.

2. Galindo Diaz $J$. The dissemination of military perspective through fortification treatises between the sixteenth and eighteenth centuries // Nexus Network Journal. - 2014. - Vol.16. - P.569585 .

3. Galindo Diaz J. La ensecanza de la perspectiva como parte de la fortificaciyn en el siglo XVIII: el caso de la Real Academia de Matemøticas de Barcelona // Varia Historia. 2008. - Vol.24. - No. 40. - P.462-482.

4. Walsh M.J.K., Coureas N., Edbury P.W. Medieval and Renaissance Famagusta: studies in architecture, art and history. - Ashgate Publishing, Ltd., 2012.

5. Chalamwong Y., Thabchumpon N., Chantavanich S. Temporary shelters and surrounding communities - livelihood opportunities, the labour market, social welfare and social security. -Springer, 2014. - $231 \mathrm{p}$.

6. Davis T.C. Stages of emergency: cold war nuclear civil defense. - Duke University Press, 2007. - 435 p.

7. Marshall A.C. Gulf war depleted uranium risks // Journal of Exposure Science \& Environmental Epidemiology. - 2008. Vol.18. - P.95-108.

8. Durakovic $A$. The quantitative analysis of uranium isotopes in the urine of the civilian population of eastern Afghanistan after operation Enduring Freedom // Military Medicine. - 2005. - Vol.170. - No. 4. - P.277-284.

9. Environmental pollution by depleted uranium in Iraq with special reference to Mosul and possible effects on cancer and birth defect rates / Fathi R.A., Matti L.Y., Al-Salih H.S., Godbold D. // Medicine, Conflict and Survival. - 2013. - Vol.29. - P.7-25.

10. Pattison J.E., Hugtenburg R.P., Green S. Enhancement of natural background gamma-radiation dose around uranium microparticles in the human body // Journal of the Royal Society Interface. - 2010. - Vol.7. - P.603-611.

Received 06.03.2018

\section{ДОСЛІДЖЕННЯ ЗАХИСНИХ ХАРАКТЕРИСТИК БЕТОНІВ НА ОСНОВІ ЦЕМЕНТІВ СПЕЦІАЛЬНОГО ПРИЗНАЧЕННЯ}

\section{Л.Я. Паращук, В.В. Кочубей, Л.І. Одосій, С.В. Королько}

У даній роботі досліджено вплив типу иементу, з якого виготовлені захисні інженерні споруди, на значення лінійного коефіцієнта поглинання радіаційного потоку. Хіміко-мінералогічний склад цементу для захисного бетону обрано таким, щоб при твердненні формувались гідратні новоутворення $з$ найбільш можливим вмістом хімічно зв'язаної води. Диференційно-термічний аналіз здійснено на дериватографі Q-1500 D системи, розробленої F. Paulik, J. Paulik ma L. Erdey. За його даними встановлено кількісний склад продуктів гідратацї̈ досліджуваних цементів. Експериментально виміряна зміна інтенсивності випромінювання (у бекерелях) після проходження через бетонні зразки, виготовлені на основі цементу ПЦ II/А-Ш та РЦВ-5. 3 використанням закону послаблення вузького моноенергетичного пучка ү-квантів при проходженні крізь речовину обчислено лінійний коефіцієнт поглинання бетонними зразками, виготовленими на основі цементів різного складу. За допомогою спеціальних, механічних $і$ фізико-хімічних методів аналізу встановлено зв'язок між процесами структуроутворення та захисними характеристиками зразків. Показано, що гідратні сполуки, які утворюються при гідратації цементної складової, забезпечують підвищення лінійного коефіцієнта поглинання, а, разом з ним, рівня захисту.

Ключові слова: цемент, гідратні новоутворення, продукти гідратації, радіаційний потік, коефіцієнт поглинання, термічний аналіз.

\section{RESEARCH INTO THE PROTECTIVE CHARACTERISTICS OF SPECIAL-PURPOSE CEMENT-BASED CONCRETES}

\author{
L.Ya. Parashchuk ${ }^{a, ~ *, ~ V . V . ~ K o c h u b e y ~}{ }^{b}$, L.I. Odosiy ${ }^{a}$, \\ S.V. Korolko ${ }^{a}$
}

a Hetman Petro Sahaidachnyi National Army Academy, Lviv, Ukraine

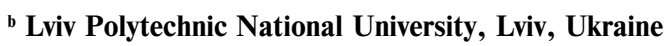 \\ * e-mail: lidadmy@ukr.net}

The effect of the cement type, from which engineering protective constructions are produced, on the value of the linear absorption coefficient of radiation flow has been investigated. The chemical and mineralogical composition of cement for the protective concrete was selected so that hydrated new-formations with the highest possible content of chemically bound water can be formed when hardened. The differential thermal analysis was conducted using a derivatograph Q-1500 D of Paulic-Paulic-Erdey system. Based on the obtained data, the quantitative composition of hydration products of cements under study was determined. A change in radiation intensity (in becquerel) was experimentally measured after passing through the concrete samples based on the Portland cement PC II/A-S 400 and the expansive Portland limestone cement PLC-5. Using the law of the weakening of a narrow monoenergetic beam of $\gamma$-quanta after passing through a substance, a linear absorption coefficient was calculated for the concrete samples of different composition. By means of special mechanical and physicochemical methods, the relationships between the processes of structure formation and the protective characteristics of the samples have been established. It was shown that hydrated compounds formed in the course of hydration of a cement constituent allow increasing the linear absorption coefficient together with raising the level of protection. 
Keywords: cement; hydrated new-formations; hydration products; radioactive emission; absorption coefficient; thermal analysis.

\section{REFERENCES}

1. Cheung Y.K., Chau K.W., Tall buildings - from engineering to sustainability. World Scientific, 2005, 1168 p.

2. Galindo Diaz J. The dissemination of military perspective through fortification treatises between the sixteenth and eighteenth centuries. Nexus Network Journal, 2014, vol. 16, pp. 569-585.

3. Galindo Diaz J. La enseñanza de la perspectiva como parte de la fortificación en el siglo XVIII: el caso de la Real Academia de Matemáticas de Barcelona. Varia Historia, 2008, vol. 24, no. 40, pp. 462-482. (in Spanish).

4. Walsh M.J.K., Coureas N., Edbury P.W., Medieval and Renaissance Famagusta: studies in architecture, art and history. Ashgate Publishing, Ltd., 2012.

5. Chalamwong Y., Thabchumpon N., Chantavanich S., Temporary shelters and surrounding communities - livelihood opportunities, the labour market, social welfare and social security. Springer, 2014

6. Davis T.C., Stages of emergency: cold war nuclear civil defense. Duke University Press, 2007.

7. Marshall A.C. Gulf war depleted uranium risks. Journal of Exposure Science \& Environmental Epidemiology, 2008, vol. 18, pp. 95-108.

8. Durakovic A. The quantitative analysis of uranium isotopes in the urine of the civilian population of eastern Afghanistan after Operation Enduring Freedom. Military Medicine, 2005, vol. 170 , pp. 277-284.

9. Fathi R.A., Matti L.Y., Al-Salih H.S., Godbold D. Environmental pollution by depleted uranium in Iraq with special reference to Mosul and possible effects on cancer and birth defect rates. Medicine, Conflict and Survival, 2013, vol. 29, pp. 7-25.

10. Pattison J.E., Hugtenburg R.P., Green S. Enhancement of natural background gamma-radiation dose around uranium microparticles in the human body. Journal of the Royal Society Interface, 2010, vol. 7, pp. 603-611. 